Article

\title{
The Process of Ethnocentralizing the Concept of Ecological Agroalimentary Products for the Romanian Urban Consumer
}

\author{
Alina Butu ${ }^{1}\left(\mathbb{0}\right.$, Codrin Dinu Vasiliu ${ }^{2} \mathbb{D}$, Steliana Rodino ${ }^{3, *}$, Ioan-Sebastian Brumă ${ }^{2} \mathbb{}$, \\ Lucian Tanasă ${ }^{2}$ and Marian Butu ${ }^{1, *}$ \\ 1 National Institute of Research and Development for Biological Sciences, 060031 Bucharest, Romania; \\ alina_butu@yahoo.com \\ 2 "Gh. Zane" Institute for Economic and Social Research, Romanian Academy, 700481 Iași, Romania; \\ codrindinuvasiliu@gmail.com (C.D.V.); sebastianbruma1978@gmail.com (I.-S.B.); \\ lucian.tanasa@gmail.com (L.T.) \\ 3 The Bucharest University of Economic Studies, 010374 Bucharest, Romania \\ * Correspondence: steliana.rodino@yahoo.com (S.R.); marian_butu@yahoo.com (M.B.); \\ Tel.: +0040-742-090-021 (S.R.); +0040+723-822-573 (M.B.)
}

Received: 3 October 2019; Accepted: 5 November 2019; Published: 7 November 2019

\begin{abstract}
In the case of the Romanian urban consumer, ecological agroalimentary products do not merely operate on the discursive line mapped by the rules of certification. The ecology of the agroalimentary products is reinterpreted and, thus, an interesting phenomenon occurs. The products perceived as natural, local, or peasant are seen as ecological enough to influence the purchase decision. Hence, according to the Romanian urban consumer, the ecological product stands for a symbolic projection provided by their own experience and trust level as a consumer. In the present paper, we aimed to go beyond the theory claiming that such behavior is determined by confusion in the social action of purchase and, following this line of interpretation, we also intended to identify the symbolic systems and hermeneutical criteria by which the Romanian urban consumer makes a social projection of ecological agroalimentary products through certain ethnocentralizing mechanisms. Our research paper was based on a qualitative and quantitative anthropological analysis that had, as a starting point, a questionnaire applied online (with a total of 1792 respondents, out of which 1342 were urban respondents).
\end{abstract}

Keywords: urban person; ecological alimentary products; health; consumers; symbolic systems; Romania; natural product; traditional product; countryside product; local product

\section{Introduction}

One of the best-known critics of the consumption society [1-4] has brought reproaches on consumerism based on the fact that it lays the foundations for a hedonist society. The first half of the 20th century marked the emergence of mass consumption, where meeting the basic needs started turning into a socioeconomic system of also satisfying pleasure and prestige.

The need for nourishment has been gradually replaced by the gourmet pleasure, while the need for clothing has turned into the desire to be trendy or fashionable. Moving, dwelling, and socializing have all acquired extra objectives: pleasure and prestige publicity including the pleasure of eating, the delight of dressing up, the comfort of one's dwelling, and the enjoyment of travelling and communicating. Therefore, the comfort, delight, and extra notoriety become criteria, according to which the added value of the goods and services we purchase is being decided. We no longer possess a body whose 
mere needs translate into survival and preservation; instead, we own a body in which we need to procure recognition and pleasure.

From the individual, regarded as a survival unit, we move onto the idea of the consumer, regarded as a unit establishing the psychosocial and socioeconomic bases. Thus, a consumption economy inevitably involves a sociology of delight. The consumption society takes us into a direct relationship with the basic necessary resources and also places us into a gearing where we are shaped in our own image and pleasures.

Regardless of how alarming these critical positions may sound, the consumption society can hardly escape the hedonism label. The consumption surplus as delight looks like a label permanently attached. The contemporary person has forever moved into that universe of pleasure generated by purchasing goods at grassroots level. A certain term has been invented, namely consumerism, to morally qualify this connection between consumption and delight [5], which conveys both the idea of consumption surplus and pleasure.

Thus, the simple fact of going shopping becomes a pleasant, private, and gender neutral activity, engaged into a daily rhythm and rituals clearly defined in a world especially created and designed for consumers. What is called the "shoppers' economy" [6] is no farther than a utopia under the purchasing mark. In this context, a little paradox is born: how does a contemporary person, subject to hedonistic consumerism, increasingly desire to live in a healthy universe? Why do we want to eat and live as naturally as it can be? Is it about a critical moment in the symbolic universe of consumerism?

All these questions are related to a systemic matter of the consumption. The entire system of the consumption society displays this sort of behavior, which is rather close to an anthropological paradox. Somewhere, along the line, a symbolic fault line occurs in the structural understanding of the entire system of the consumption society when we are discussing the hedonistic nature of the whole assembly, and the health wish, as it has been increasingly noticed among the emerging individual behaviors.

For the reasons presented above, these are precisely the main questions, the ones we ask ourselves when the Romanian urban consumers of ecological agroalimentary products are in question. Starting from the data gathered through the above-mentioned questionnaire, we shall attempt to understand how the ecological concept reaches certain adjustments between two apparently opposed symbolic systems: consumption and a healthy life. The current paper does not intend to analyze the impact of the ecological food products upon health, but the manner by which the concept of ecological food products goes through resemanticization in the interaction area of these symbolic systems.

\section{Methodology}

Having these questions as a starting point and based on the analysis of the data obtained by means of a nationwide questionnaire, we propose the following working hypotheses:

- We are dealing with an increased responsibility of the Romanian urban consumer regarding the purchase of food products; and

- This increase of responsibility is not decisively determined by the ecologically certified products, but rather by certain local reactions toward the globalization phenomenon. These reactions are closely connected with the imagining of healthy alimentation and with the discourses that have an influence on trust in what concerns food safety and security.

Therefore, the concept of ecological food product goes through a process of ethnocentralizing and obtains connotations that no longer regard the ecological certification. It concerns a phenomenon that does not involve a confusion, but rather the pressure put by the collective imaginary on the semantics of the concept of ecological food products.

In 2016, the interdisciplinary research group known as Rural Development Research Platform developed a questionnaire on the behavior of the Romanian consumers of ecological agroalimentary products. The questionnaire was conducted nationwide and mostly applied online through Facebook and email. In the case of Facebook, it employed various pages, groups, and the private accounts of some 
authors who wrote the present article. The questionnaire was posted on the following Facebook pages and groups: Rural Development Research Platform (with an audience of 1889 persons); Eco Ruralis-an association of peasants from Romania (with an audience of 11,948 persons); Regiunea de Dezvoltare Nord-Est (4496 members); Iasul vrea produse locale (over 36,000 members); Iasiul vrea produse naturale (over 39,000 members); Targuri si manifestari taranesti (290 members); Iasiul vrea produse naturale din gospodării (over 10,000 members); Academia Română, Filiala Iași (with an audience of 2633 persons); Institutul de Cercetări Economice şi Sociale "Gh.Zane" (with an audience of 325 persons); and so on. The above-mentioned questionnaire was also sent on by email to approximately 400 email addresses and registered a response rate of roughly $10 \%$.

The questionnaire was conducted on a sample of 1792 people across Romania. Out of the 1792 answers received, 1613 were validated. Among these, 1342 people lived in the urban space of Romania. Regarding the urban respondents 'age, according to gender, out of the total respondents, there were 423 male $(31.5 \%)$ and 919 female respondents $(68.5 \%)$. Based on the age category, 14 respondents $(1 \%)$ were up to 18 years old, $218(16.2 \%)$ were between 18 and 25 years old, $642(47.8 \%)$ were between 26 and 40 years old, while 441 (32.9\%) were between 41 and 65 years old, and $27(2.0 \%)$ were ranged over 65 years old. According to educational background, urban respondents fell under the following categories: 544 (40.5\%) had post-graduate degrees, $643(47.9 \%)$ graduated college, $148(11.0 \%)$ graduated from high school, and seven $(0.5 \%)$ graduated from secondary school.

Within the questionnaire, 20 questions were introduced regarding gender, age, civil status, children in care, family monthly income, main activity, frequency of ecological alimentary products purchase, acquisition of other ecological products, main reason for buy eco-friendly products, place of purchase, main criterion for identifying eco-friendly food products, what does eco-friendly food product mean, degree of trust in the ecological products, the official logo of the ecological products in EU, the most important source of information, the most used device for Internet surfing, and how eco-friendly food products could be best promoted.

A series of these questions had already been addressed in a previous study [7] that focused primarily on a purchase decision analysis of ecological agroalimentary products. Following the writing of the above-mentioned study, the research team reached a conclusion that could not be fully explored within that particular paper: that, in Romania, although consumers of ecological agroalimentary products are aware and informed about the ecological certification and easily recognize the labels of ecologically certified products, they also chose to interpret the meaning of the concept of ecological agroalimentary products according to their own experiences and financial means. The certification itself was not sufficient motivation to force an understanding of healthy alimentation within the official conceptual delimitations of ecological alimentary products.

Along these lines and based on the study mentioned earlier, we reached the conclusion that the idea of ecological agroalimentary products is the object of a mental projection that regulates itself, especially within the symbolic system of relating to a healthy life. These symbolic projections and structures lead to formulating some uncommon selection criteria in the purchasing process of food products. At the same time, based on these subjective criteria of selection, the Romanian urban consumer seems rather more interested in purchasing products as ecological as possible without paying much attention to the officially accepted certification. In other words, the Romanian consumer is more interested in purchasing what corresponds as much as possible with their own interpretations on the ecological agroalimentary product, rather than on the fact that a certain product is certified or not.

To further advance this research, the present paper aimed to analyze the symbolic mechanisms by which the Romanian urban consumer decodes the semantics of the ecological concept in its private contexts as well as the ways in which these contexts lead to a resemanticization of the ecological concept.

Therefore, we would like to explore the following:

- The consumption community and the ethnological contexts of purchasing food products.

- The symbolic systems of consumption and health together and the interactions between them. 
- Constituting the ecological concept as a legitimizing narrative of the interaction between the symbolic systems of consumption and health.

- Resemanticization of the ecological concept in the conceptual zone of traditional, local, and peasant products.

This paper used both a qualitative and quantitative approach. Our analyses concerned both the anthropology of the Romanian urban consumer, as they been revealed from the literature and our own observations, and the quantitative data were obtained by applying our questionnaire.

The graphics of the data employed in the present study were made with the assistance of Microsoft Excel and the statistical application R Program [8-10]. In the case of R Program, the following work package was used: multiple correspondence analysis (MCA) to identify the strongest correlations [11-13].

\section{Preliminary Data}

\subsection{Reductionism in Understanding the Ecological Agroalimentary Product}

On quite a few occasions, the consumption society has been regarded through the lenses of reductionism. This perspective can put at risk the understanding of this society viewed as an automatic phenomenon that should be exclusively regulated in accordance with the official regulation. In the case of the present analysis, we would like to highlight two of these reductions.

The first type of reductionism resides in the idea that between conventional agriculture and ecologically certified agriculture, there are fundamental differences regarding food security. We see the agroalimentary products obtained from conventional agriculture as a non-ecological product by far, while, in what concerns the certified product, we consider that it possesses all the ecological arguments related to food safety and security. The opposition between conventional and certified becomes an exclusive one, at least, by the manner in which these two terms are in absolute opposition.

This reductionism has, at least, two side effects in terms of mentality and functionality:

- It reduces the importance of the short food supply chains in terms of food safety and security; and

- It places the entirety of conventional agriculture in opposition to sustainability and durability.

To further explain why we believe we are not dealing with a confused consumer, we need to point out a few aspects connected to the culture of imaginary of the consumer. Sociologically speaking, Romanian urban consumers can be seen as a consumption community as they share common symbolic systems. Thus, the perceptions, representations, emotions, ideas, preconceptions, and their actions are influenced, to a lesser or greater degree, by the same discourses that circulate openly in the public space and are also at the level of the common imaginary. These discourses work as legitimizing narratives [14] and become interpretative agents that either balance or unbalance the link between the symbolic systems. In this case, these legitimizing narratives intervene at the level of tension between the symbolic system of consumption and that of health.

For instance, the fact that peasant agroalimentary products are seen as ecological products does not create confusion, but a legitimizing narrative by which this consumer is trying to balance the symbolic system of consumption with the symbolic system of health. Such a legitimizing narrative is backed by a personal history, a subjective system of valorization, a set of purchase routines, and last but not least, an individual or family interpretation on alimentary consumption.

A second type of reductionism worthy of attention regards the preconception according to which we are dealing with a confused consumer [15-17]. The Romanian urban consumer is indeed confused as long as he/she, by their purchase decision, does not identify the ecological agroalimentary product as strictly the ecologically certified agroalimentary product. Resting on this reductionism lies the idea that we are dealing with a bidimensional concept of the ecological product, where the production and commercialization are the only dimensions where the certification occurs. Actually, the consumption, 
especially through the purchase decision, introduces a third dimension in this configuration system of the ecologically certified products.

These legitimizing narratives, as shown further, reconfigure the concept of ecological agroalimentary products and have the following consequences:

- Resemanticization of the ecological concept in the traditional, local, and peasant areas (ethnocentralization of the ecological concept).

- Raising the importance of memory and sensorial impact in the purchase decision of ecological products.

In the beginning, we shall present the fundamental data of these two symbolic systems, namely the urban consumption of food products and health.

\subsection{The Symbolic System of the Urban Consumption of Food Products}

The analysis of the consumption symbolic system may very well commence from an idea expressed by Gilles Lipovetsky, that "The consumerism civilization is defined by the central place occupied by the expectation to well-being and the search for a better life for himself/herself or his/her own family." [6]. Three issues are worth remembering in this quotation: The consumer is determined by the expectation to well-being, improved life quality, and family context. We could add that as a consumer, their aspiration to wellbeing conditions his/her satisfaction; the improved life quality determines his/her objectives on a daily basis; while the family context defines his/her immediate space of valorization and action.

Based on these three coordinates, in the case of the Romanian urban consumer, we can safely make the following observations regarding the purchase symbolic system of the food products:

a) In the case of urban consumers from Romania, the food supply sources are as follows: hypermarkets, supermarkets, farmers' markets, wholesale markets, specialized shops, online shops, producers' shops or stands, fairs, gastronomic festivals and events, brunches organized by producers, mobile markets, straight from the farmgate, or other forms of innovative short food chains of supply. The largest percentages on the food product consumption are registered in the retail shops and farmers' markets.

b) The metropolitan territorial organization is relatively identical in Romania. Hence, in what concerns the purchase centers of agroalimentary products, their location is quite the same in each town/city in Romania. The hypermarkets are generally located at the outskirts of a city/town, while supermarkets and farmers' markets are found in the busy and populated areas [18]. In the case of metropolises, almost every neighborhood has its own farmers' market and, at least, one supermarket.

At the same time, as Cristian Dragoş and Vincenţiu Vereş state, at present, in Romania, farmers' markets still occupy a privileged position and remain competitive through price, proximity, freshness, and quality of the agricultural products, and also in the range of agricultural products [19]. Regarding the smaller cities/towns, the presence of supermarkets, malls, or hypermarkets can produce a recreational type of consumption phenomenon or display of social prestige, behaviors that go beyond the simple motivation of going shopping for supply reasons.

c) Concerning the anthropology of the visit paid to the supermarket, it should be highlighted that urban Romanians are more daily shoppers than weekly ones. The supermarket purchase reveals a rather completing behavior of the daily needs than that of a long-term supply. This phenomenon can also be influenced by the following facts: supermarkets are generally located at a short-distance walk/drive from the consumers' dwelling; most supermarkets are open from Monday to Sunday inclusive, and from early hours in the morning (some as early as 6 a.m.) till late evening (10 p.m.). The long-term purchase is generally made in the farmers' markets. 
d) The extra-urban peasant fairs are increasingly seldom visited by the urban consumer. They are mainly spaces serving for peasant exchanges. There are also the so-called wholesale markets located in the urban areas and which are practically taken by storm every autumn when most Romanian consumers buy large quantities of agroalimentary products to prepare home-made canned food for winter (jams, canned vegetables, tomato juice, fruit compotes, and many others). Many of the Romanian urban consumers are still preparing these home-made canned foods (before 1989, during the communist regime, this was a frequent and necessary activity for almost any Romanian household). This aspect can be explained by either tradition or due to the fact that the products offered by the big producers do not satisfy these buyers in terms of taste or because the traditional products offered by the small producers are considered too expensive.

e) To better understand the subjective and objective determinations of the food consumption, a few clarifications should be made in terms of what concerns the consumption context of the basic food products.

Bread-The product always present on a Romanian kitchen table is bread. Romanians are one of the largest consumer groups of bread worldwide [20], and they occupy first place in Europe on bread consumption [21]. Concerning the agricultural areas of cereals cultivated in an ecological system, wheat occupies the first position in Romania, registering over 45,000 ha in 2017 [22]. Both bakers' wheat (Triticum aestivum) and durum wheat (Triticum durum) used for making bread and pasta are cultivated in Romania.

Despite these facts, ecologically certified bread is hardly found in the big retail shops. It is commonly present in specialized stores and less easily sold. Most varieties for sale fall within the category of white bread (around $65 \%$ out of the total of bread consumption) [23]. This is a purchase behavior that seems largely motivated by taste, and not one related to nutritional values.

Meat-Chicken and pork are among other food products often purchased by the Romanian urban consumer. Beef is also highly appreciated, but it is less consumed due to its relatively costly price. Similar to the case of bread, there is a relatively low offer of ecologically certified precooked meats products.

Eggs-Romanian cuisine values eggs as basic products that are either consumed by minimum cooking (boiling or frying) or as ingredients for many traditional recipes. In the retail shops, the offer of ecologically certified eggs is quite well-supplied. The 0 (zero)-marked eggs come from ecological production as there are strict regulations related to the rearing areas, wellbeing standards, fodder, and medical treatments administered to the laying hens (the birds are fed with ecologically certified, pesticide, and hormone-free fodder only, without antibiotics or other synthesis substances) [24].

Fish-In Romania, fish consumption is quite significant, although the Romanian consumer does not excel at this food chapter. Fish farmed in an ecological system is barely present on the market. However, the Romanian consumer chooses freshly caught fish when they wish to buy a healthy product.

Dairy products-Related to cheese, the variety is considerably lower than that of other countries with long traditions such as France, Italy, Switzerland, Spain, and others. Romanians, except for some geographical regions, do not have a strong tradition in matured cheeses. The offer of ecologically certified products is also low. The purchase decision is mainly focused on traditional, local, or peasant products. In comparison to other European gastronomical cultures, sour cream is among the most consumed dairy products in Romania. Yogurts register high percentages in preferences along with milk, which has the widest offer of ecologically certified dairy products. Butter is another highly appreciated dairy product in Romanian cuisine. 
Maize-Maize flour is largely used as a prime ingredient in "mămăligă" (a sort of maize porridge similar to Italian polenta). "Mămăliga", quite legitimately, has often been associated with the history of Romanians [25]. Gastronomically speaking, "mămăliga" successfully replaces bread in association with foods based on cheese, eggs, or meat (and often combined). Romania is also an important maize producer for both human and animal consumption and, recently, as a novelty, for bio fuel production [26].

The maize crop in the ecological system occupies the second position after wheat (approximately 20,000 ha cultivated in 2017). However, the yield is largely used as fodder for the animals raised ecologically [22].

Herbs-In Romania, the most purchased herbs are parsley, lovage, dill, and lettuce. Green onion and garlic are also associated with herbs and are often consumed. Ecologically grown herbs like parsley, lovage, and dill are entirely absent. There is a rather limited offer of ecologically certified lettuce.

Tomatoes-These are one of the most symbolically loaded aliments among the agroalimentary products for the Romanian consumer. Tomatoes are chiefly consumed during summer as the consumers favor the Romanian varieties that are considered much tastier than the imported ones. Tomatoes can be generally bought from the farmers' markets and the most important purchase criteria are the following: peasant or rural nature, variety, and area where they were grown. There are offers of ecologically certified tomatoes in the retail shops, but, in spite of this, the tomatoes labelled as Romanian peasant product are preferred during the growing season. On quite a few occasions, the Romanian urban consumer can be heard talking about "imported or supermarket tomatoes that taste like rubber".

Other vegetables-Romanians frequently eat potatoes, beans, carrots, celery, parsnip, onion, garlic, bell peppers, red peppers, hot peppers, eggplants, marrows, and cucumbers. The native peasant products are generally favored in the case of these vegetables. The offer of ecologically certified products is barely present on the market.

Fruit-These are among the most consumed products (fresh, dried, frozen, or canned). The most diversified offer of ecologically certified fruit is for apples, pears, strawberries, blueberries, raspberries, sea buckthorn, citrus fruits, and bananas.

Honey-Romanian honey is a highly successful product both nationally and internationally. It is also one of the high-quality products obtained in Romania. The offer of ecologically certified honey and apicultural products is quite generous.

Edible Oils-The consumption of cooking oil is fairly high as Romanian gastronomy has many recipes that involve tempering and frying. The most consumed oil is sunflower.

Beer and wine-In terms of legislation, in Romania, beer and wine fall within the category of aliment. Concurrently, the beer consumption is quite high in Romania (1.4295 L per capita monthly, Table 1), which places Romania in seventh position in the world. However, ecologically certified beer is barely present here. The quality beer consumption is as high as 50\% [27]. Regarding the wine consumption, the Romanians register as drinking 0.887 L per capita monthly (Table 1 ). The ecologically certified wine offer is much more diversified and generous in Romania.

To visualize the data on consumption, Table 1 presents the processed data provided by the Romanian National Institute of Statistics [28]. 
Table 1. Average consumption of agro-food products and alcoholic beverages, by residence area in 2015-2018 (monthly average quantities per person) [28].

\begin{tabular}{cccc}
\hline Products Categories & \multirow{2}{*}{ MU } & \multicolumn{2}{c}{ Average Consumption } \\
\cline { 3 - 4 } & & Total Households & Urban Households \\
\hline Bread and bakery products & $\mathrm{kg}$ & 8.216 & 7.723 \\
\hline Maize flour & $\mathrm{kg}$ & 0.804 & 0.539 \\
\hline Fresh meat & $\mathrm{kg}$ & 3.482 & 3.640 \\
\hline Preparations of meat & $\mathrm{kg}$ & 1.166 & 1.187 \\
\hline Fish, fish products and tinned fish & $\mathrm{kg}$ & 0.722 & 0.768 \\
\hline Milk & 1 & 5.743 & 5.618 \\
\hline Dairy products & $\mathrm{kg}$ & 1.398 & 1.458 \\
\hline Eggs & $\mathrm{jieces}$ & 13.463 & 13.112 \\
\hline Maize, sunflower and soya oil & $\mathrm{kg}$ & 0.886 & 0.905 \\
\hline Fruit & $\mathrm{kg}$ & 3.862 & 4.374 \\
\hline Potatoes & $\mathrm{kg}$ & 3.087 & 3.008 \\
\hline Vegetables and tinned vegetables in equivalent fresh vegetables, total & $\mathrm{kg}$ & 7.835 & 7.950 \\
\hline Tomatoes & $\mathrm{kg}$ & 1.089 & 1.192 \\
\hline Sugar & $\mathrm{kg}$ & 0.742 & 0.739 \\
\hline Honey & $\mathrm{kg}$ & 0.080 & 0.095 \\
\hline Wine & 1 & 0.887 & 0.632 \\
\hline Beer & 1 & 1.4295 & 1.441 \\
\hline
\end{tabular}

In Romania there are [22]:

- Sixteen ecologically certified units for manufacturing grain mill products, starches, and starch products and nine similar units for manufacturing bakery and flour products;

- $\quad$ Five ecologically certified plants for meat processing, preservation, and production and also three similar plants for processing and preservation of fish and shellfish;

- Twenty-two ecologically certified facilities for manufacturing dairy products; and

- Eleven ecologically certified units for producing vegetable oils and fats as well as animal fats.

f) In Romania, as happens elsewhere worldwide [29], fruit and vegetables are apparently the most sought products among the ecological alimentary goods. On the other hand, in what concerns the availability of the ecological agroalimentary products on the Romanian market, as a general observation, it can be stated that most food products are imported [30].

g) On the whole, the Romanian consumer is an occasional buyer that interested in all categories of alimentary products and also a seasonal one with respect to fruit and vegetables.

h) Concerning this gastronomical context, the lack of ecological certification or the low number of ecological certifications on certain food product categories is further determined by the perception of the Romanian consumer who regards local, traditional or peasant products as highly valuable in terms of prophylaxis, nutrition, sentiment (taste memory), or sensorial perception (taste, smell, appearance). Hence, the small producers would rather not invest in ecological certification since they are aware of their market advantage, as long as they are local producers and their products fit into the segment of traditional or rural products.

\subsection{The Symbolic System of Health}

The symbolic system of health, as much as the symbolic system of consumption, has certain determinations related to historical memory. Certain things that occurred during the communist regime, in spite of the 30-year period, had a strong impact that is still hard to ignore.

Thus, there arises the need to highlight some particular facts such as, during the communist period before 1989, the system would censor the public exposure of the disaster in matters of the population's 
health and medical system. Illness was mostly perceived at a family level. Being ill was a private phenomenon that had a quiet course within the family context and without any public exposure by which the severity of the situation could be exposed somewhat. At the same time, the discourses of prophylaxis were few in a society profoundly affected by the lack of food in the alimentary shops. Almost no one had an issue with fats. Cholesterol was a medical term largely used by professionals and the elderly who were constantly exposed to heart diseases. Preservatives were sought, not avoided, as they helped to preserve aliments for longer periods (Romanians have a real cult for preserving fruit and vegetables over winter). The food additives were never mentioned, although the Romanian chemical industry was quite advanced.

After the fall of the communist regime, in the 90s, the Romanian market became a veritable sponge for low-quality food imports [31] as there were little or no food safety and security regulations in place. At the same time, agriculture went through another crisis, while local products were replaced by food goods imported from the USA or Turkey (in the 90s), Spain, Italy, Holland, Israel (after 2000), and many others. The common feature of all these imported goods was the undeniable inferior taste in comparison with the native local products.

This phenomenon is still very much alive since the only local agroalimentary products that made it on the market are obtained where there is a strong agricultural family tradition, namely the green houses and solariums from zones of long tradition in this field of activity.

Thus, health has started being associated more and more with the quality of food products. Furthermore, over time, the Romanian consumer has started to lose their trust in certain imported products, goods originating from the extensive agriculture or highly cheminized agricultural production.

The censorship of illness, poor alimentation, and corruption [32] has also eroded trust in the medical system. Hence, at present, and related to the Romanian urban consumer, the most widespread representation of health lies in the inverse need of seeing a doctor. Being healthy equals being as far as possible (in time and space) from a hospital. According to a IRES (Romanian Institute for Evaluation and Strategy) survey made in 2011, 78\% of Romanians are discontent with the medical services in relation to the sums of money paid for health insurance [33]. Concurrently, merely 39\% of the Romanians trust the state hospitals and $65 \%$ of them believe in private clinics or hospitals. Problems such as corruption, hospital-acquired infections, and lack of qualified personnel are reasons enough to keep the Romanian consumer in a constant fear of medical facts.

Another determinant of this symbolic system lies in the over excessive concern of the Romanian consumer regarding health. Vintilă Mihăilescu asserts that Romanians have the highest concerns about health in Europe [34] and affirmed it by noting an alarming increased rate of self-medication and consumption of nutritional supplements. In this case, a role has been also played by the tacit consent of the mass-media [35], which has largely promoted this trend on "the new health" of the consumer. Thus, occasionally, the concern about one's own health and family creates its particular symbolic systems off the medical grid, outside the officially designated institutions that manage the medical activities and discourses. The failure of trust has turned the Romanian consumer into an individual that would rather be on their own, rather than rely on such systems, especially if the situation allows it.

As we shall notice further, the same thing occurs in the case of purchasing ecological agroalimentary products. A similar mistrust surfaces when both certified or uncertified food goods are involved, either as traditional, local, or peasant products. Every consumer develops their own assessment and selection system for the ecological agroalimentary products and this fact has important consequences on the symbolic representation of the ecological concept.

\subsection{Debates and Interpretation}

In the above sub-chapters, we introduced the key data of the symbolic systems regarding food product consumption and healthy lifestyle. We further aimed to identify the legitimizing narratives by which the Romanian urban consumer tried to find a compromise solution that is somewhat able to 
balance these two systems. The starting point of this compromise is the very expectation of wellbeing, improved life quality, and family context.

To identify the legitimizing narratives of the consumption of ecological agroalimentary products as healthy products and starting from the earlier-mentioned questionnaire, we first analyzed the consumption context based on monthly family income, marital status, children in care, and the purchase frequency of ecological agroalimentary products.

Table 2 presents the distribution of monthly family income and comfort level provided by this income.

Table 2. Comfort level according to monthly family income.

\begin{tabular}{cccccc}
\hline Monthly Family Income in Lei & Monthly Family Income in Euros & Comfort Level & Total & Married & Single \\
\hline Up to 800 Lei & Up to 178 Euros & Very low & 58 & 11 & 47 \\
\hline 801-1500 Lei & Between 178 and 334 Euros & Low & 148 & 42 & 106 \\
\hline 1500-2500 Lei & Between 334 and 556 Euros & Medium & 194 & 137 & 157 \\
\hline 2501-4000 Lei & Between 556 and 890 Euros & Over medium & 385 & 241 & 144 \\
\hline Over 4000 Lei & Over 890 Euros & High & 449 & 333 & 116 \\
\hline
\end{tabular}

Furthermore, Figure 1 presents the monthly family income according to the marital status of the respondents and whether or not they have children in care.

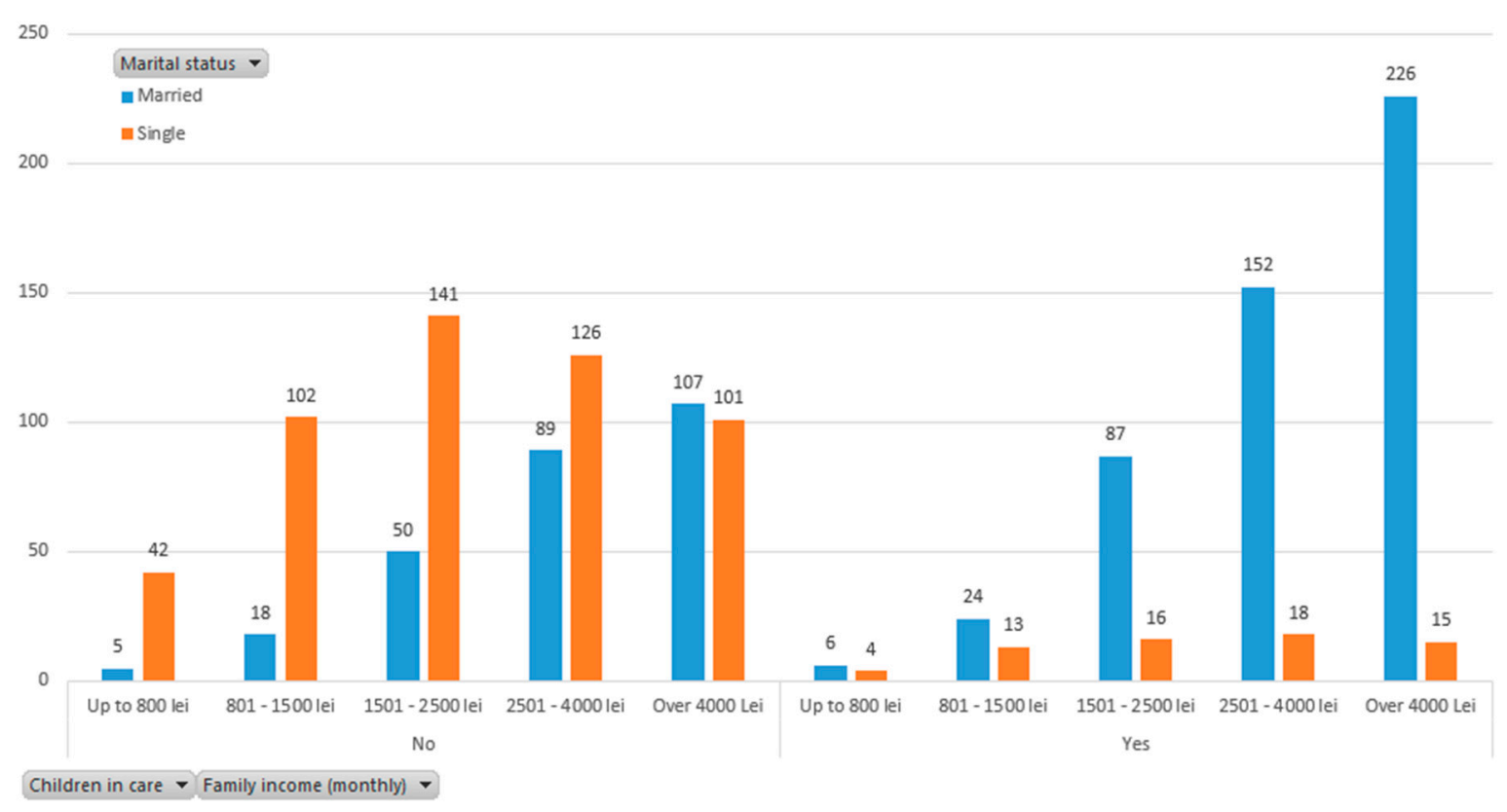

Figure 1. The monthly family income according to marital status and whether there are children in care.

Figure 2 introduces the purchase frequency of the families whose monthly income is under 4000 Lei (890 Euros) and whether there are children in care involved. 


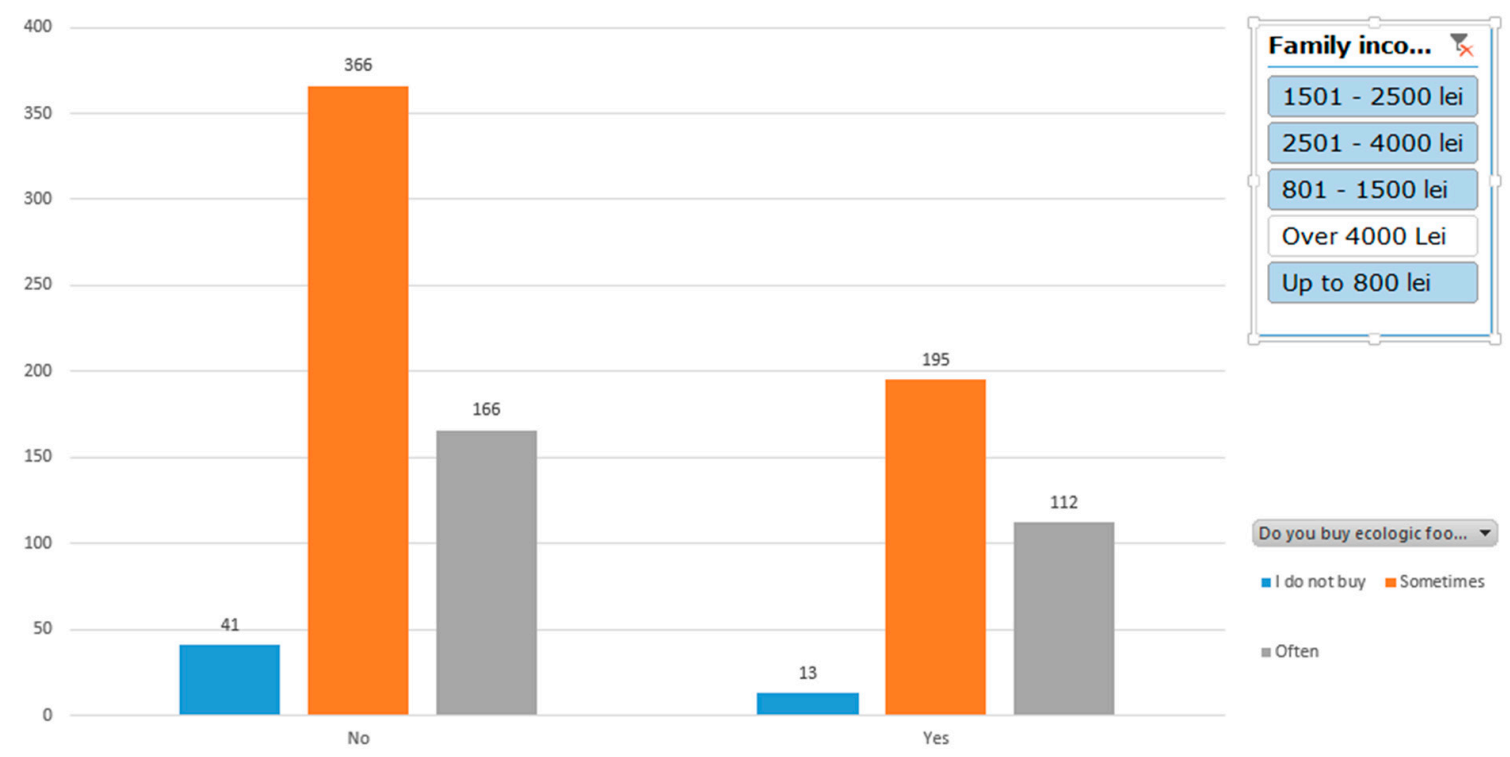

Children in care -

Figure 2. The purchase frequency rates of the ecological agroalimentary products for families with or without children in care, where the monthly family income ranged between 800 Lei (178 Euros) and 4000 Lei (890 Euros).

In Figure 3, the purchase frequency is displayed concerning the families with a monthly income exceeding 4000 Lei (890 Euros) and with or without children in care.

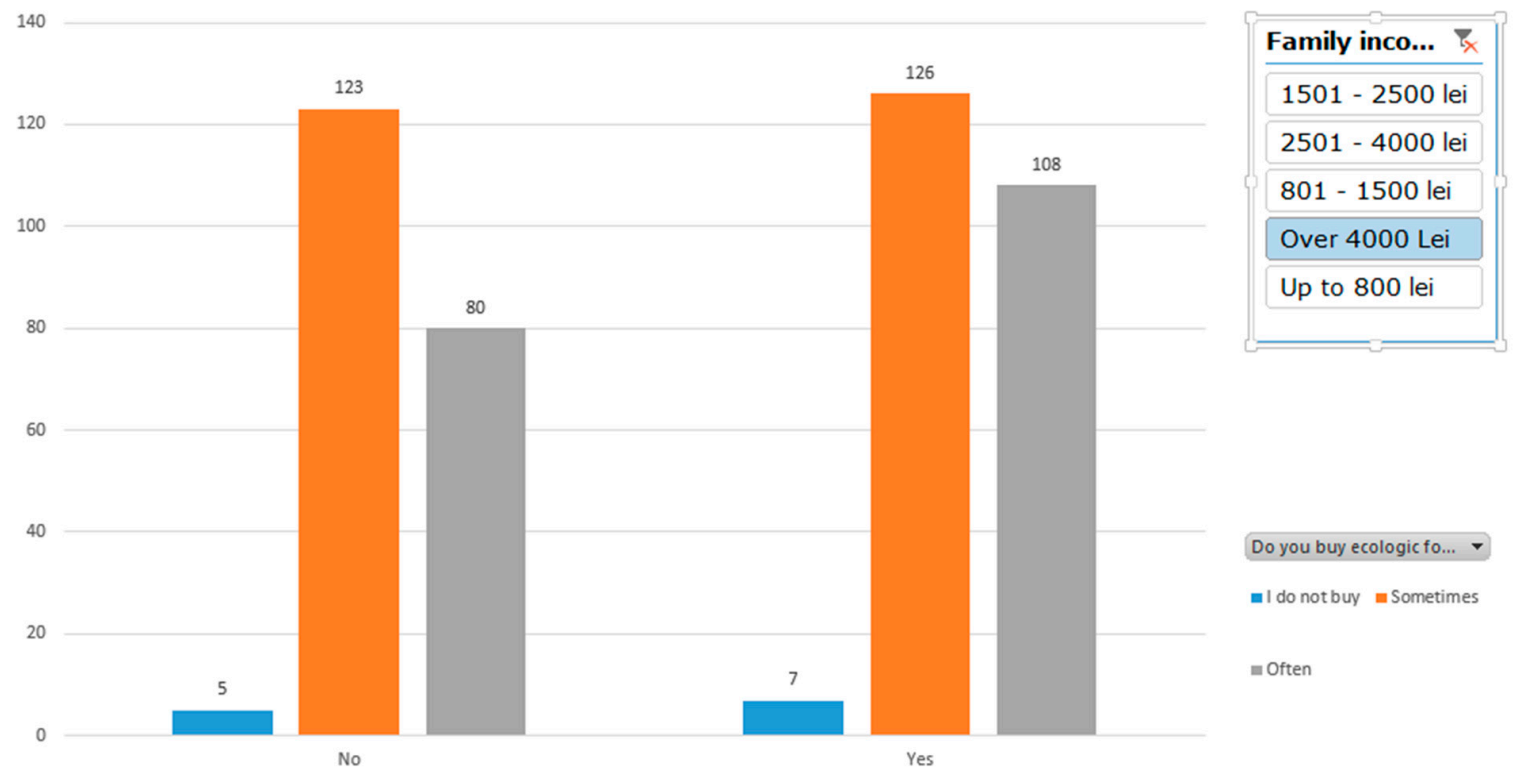

Children in care -

Figure 3. The purchase frequency rates of the ecological agroalimentary products in families with or without children, whose monthly family income exceeded 4000 Lei (890 Euros).

In Figure 2, it can be observed that in the case of the consumers whose monthly family income ranged between 800 Lei (178 Euros) and 4000 Lei (890 Euros), with or without children in care, the number of those who occasionally or often bought ecological agroalimentary products was higher than the number of those who had the same monthly income but had children in care.

In turn, regarding the group of respondents whose monthly family income exceeded 4000 Lei (890 Euros) (Figure 3), the values were closer for both families with children in care and families 
without children. Additionally, the ratio between those who bought often and those who had children in care turned in favor of those having children.

However, perhaps the most interesting fact is that the percentage of those frequently buying ecological agroalimentary products was higher in the group of families with children in care $(81.2 \%)$ than in the group of those without children in care (62.5\%). Hence, we could discuss the purchase direction according to family context.

Conforming to the data above-introduced, if we are to take into consideration the monthly family income as a key factor for the wellbeing and improved life quality, the following conclusions should be formulated:

- Most subjects have a fairly limited comfort zone. The financial resources provide limitations for a living where the basic necessities of an individual and their family are met.

- Most respondents have not crossed the minimum comfort limit toward prosperity.

- We can conclude that most subjects are in a challenging situation where they constantly struggle to make ends meet. Income and expenses are monthly challenges for most subjects whether they are married or single, and with or without children in care.

However, under the circumstances, an interesting thing occurs. As long as the difference between the minimum comfort zone and prosperity is significant, the respondents should largely declare that they do not purchase ecological food products due to financial limitations. Or, at least, they should declare that they do not often purchase such items. However, the answers are not in line with this hypothesis. As observed in Figure 4, those who did not buy ecological agroalimentary products belonged to the group of respondents whose monthly family income was up to 800 Lei (178 Euros).

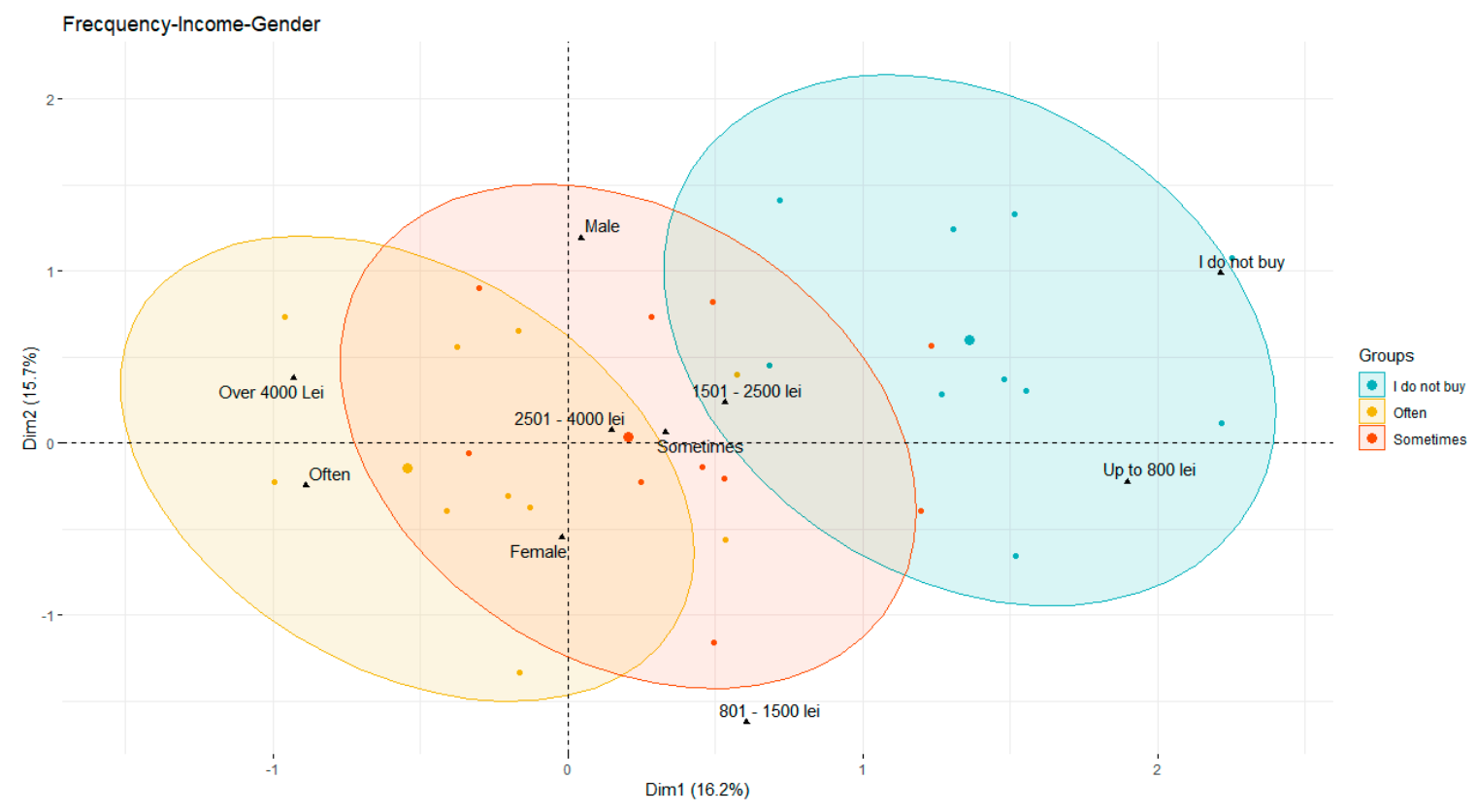

Figure 4. The purchase frequency on groups of monthly family income.

If we also link these similarities to the level of trust (Figure 5), we notice a correlation between the purchase frequency and the trust in agroalimentary products. Those who do not trust ecological agroalimentary products are also among the most people who do not buy such products. Additionally, those who have a medium or high level of trust are the majority, who occasionally or frequently buy ecological agroalimentary products. As it is further visible, trust is the main vector for mentally configuring the idea of ecological products as well as for the purchase decision. 


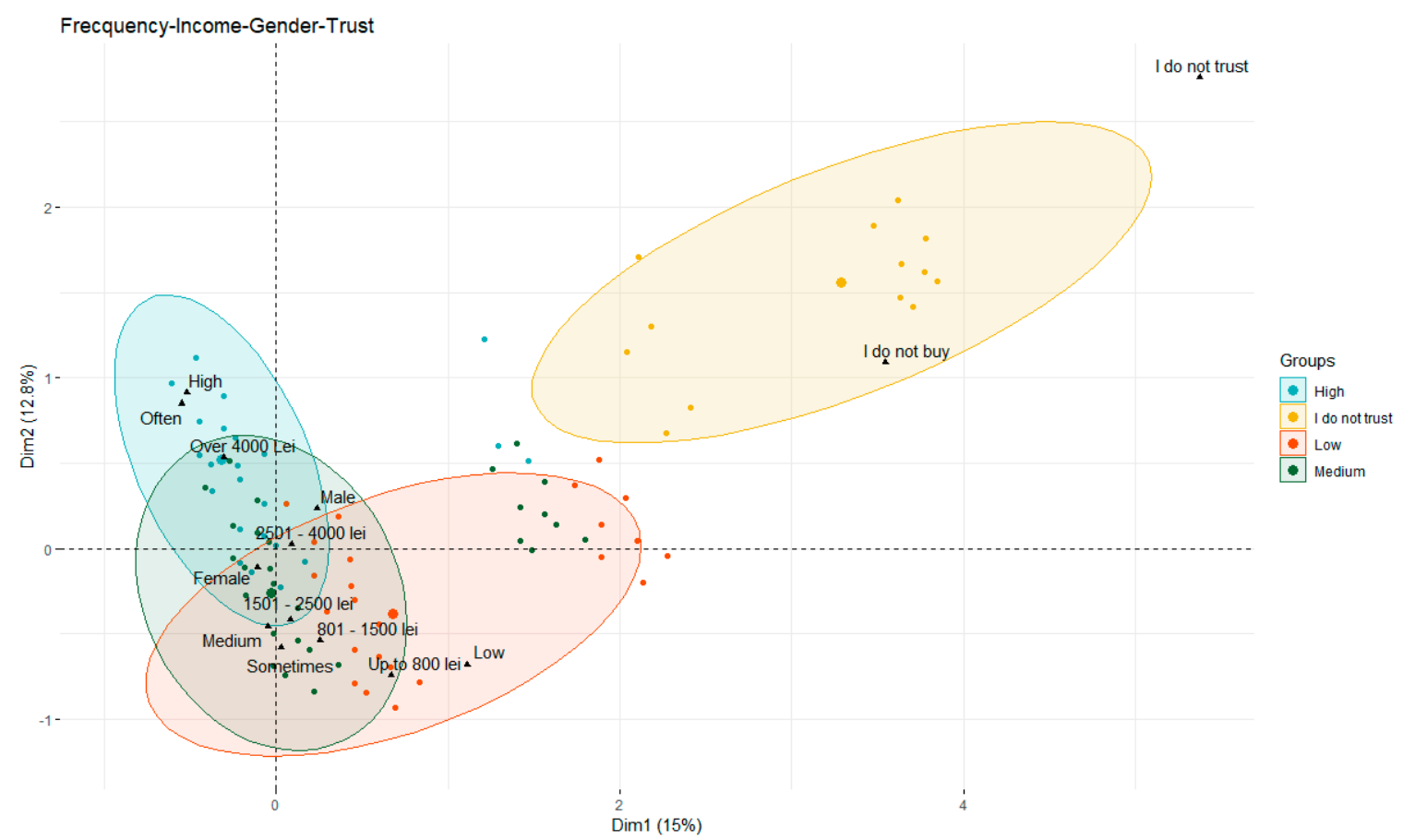

Figure 5. The multi-variable analysis of the similarities among trust level in the ecological agroalimentary products, purchase frequency, and monthly family income.

On the other hand, as it shown in Figure 6, the Romanian urban consumer has a medium and high level of trust in ecological agroalimentary products.

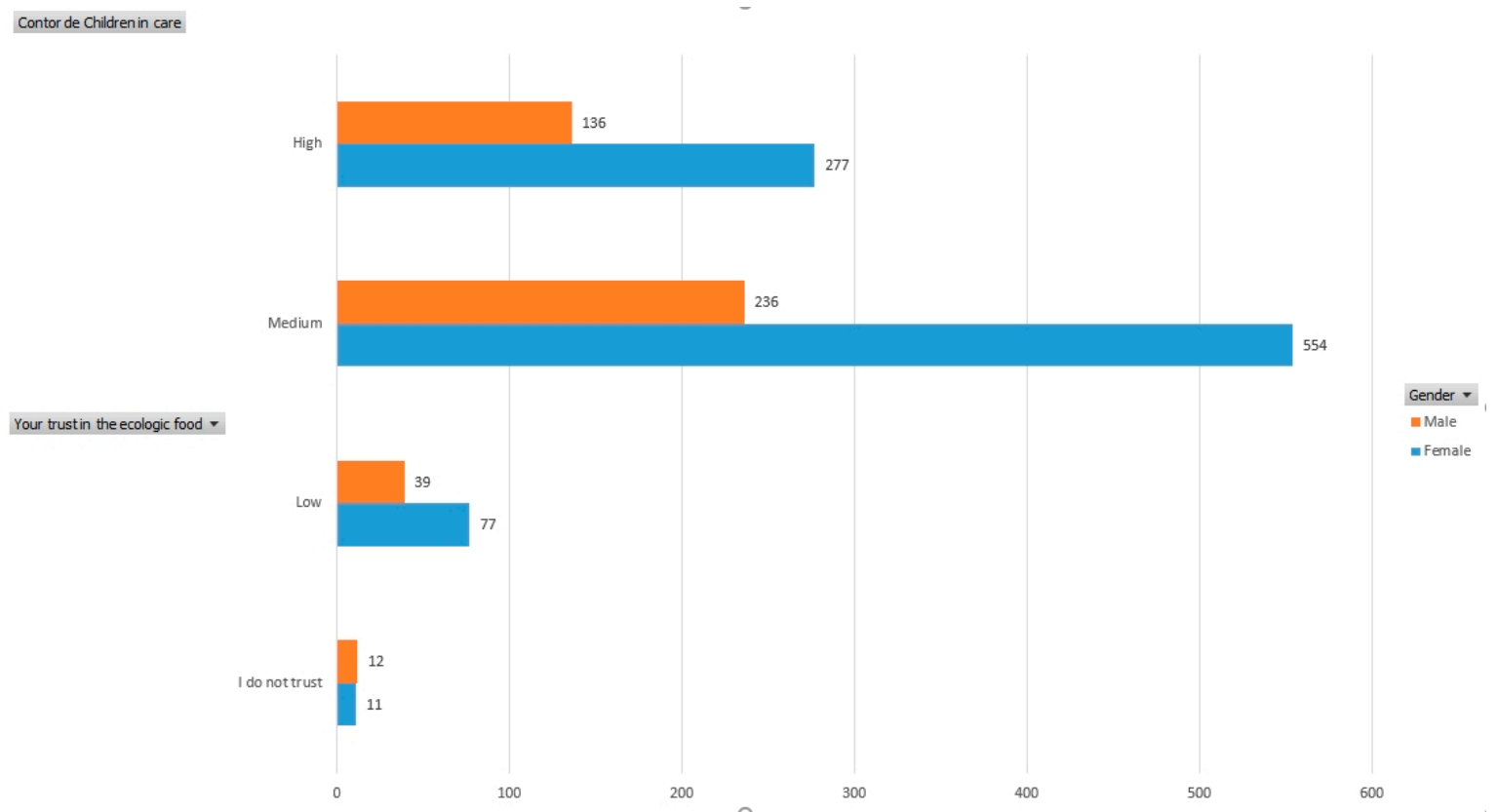

Figure 6. Level of trust in the ecological agroalimentary products.

In addition, the tough nucleus of those who do not buy nor trust such products (or they have a low level of trust) was quite low, as can be seen in Figure 7. Merely $35(2.60 \%)$ of the respondents were part of this tough nucleus. 


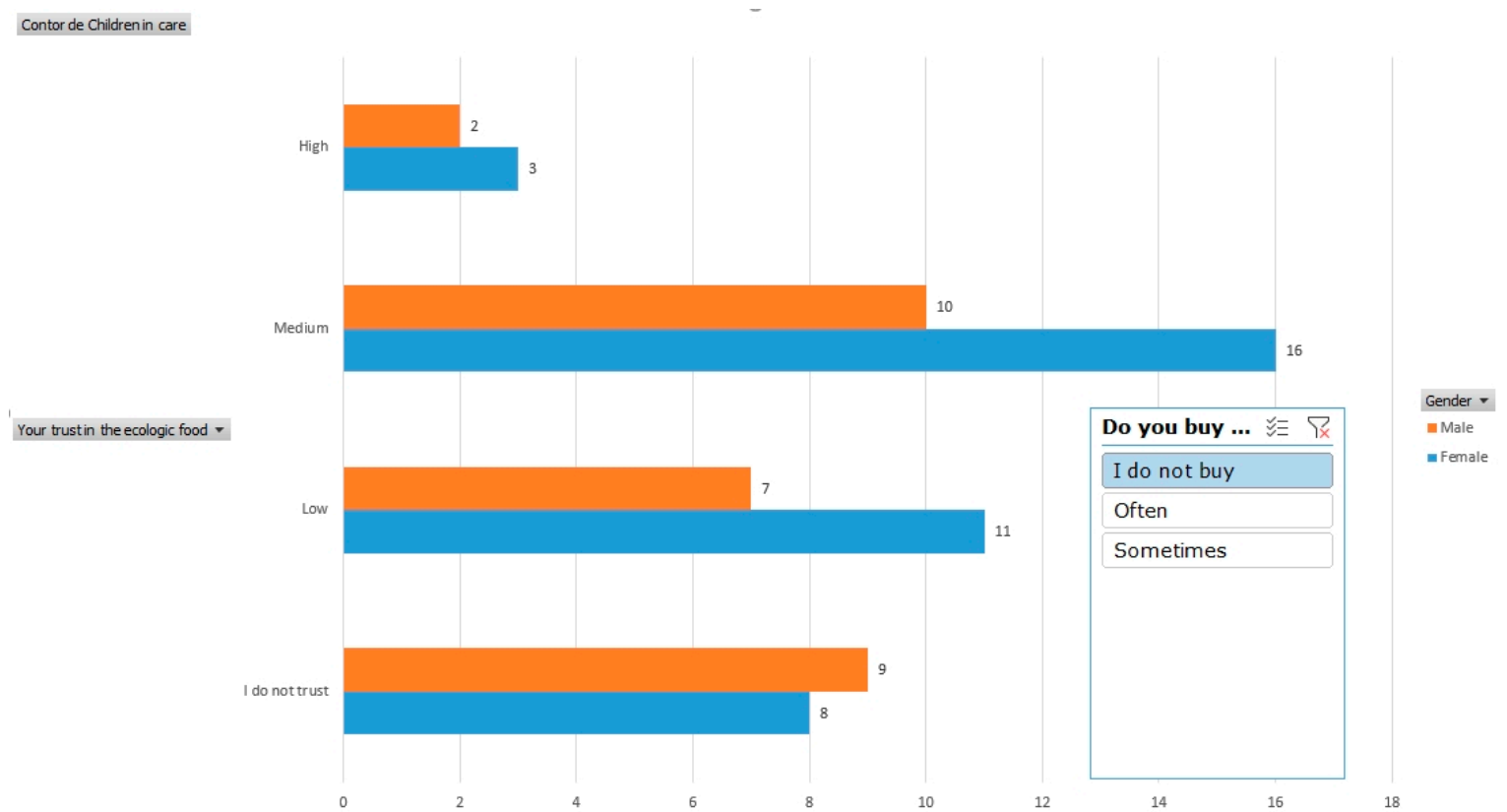

Figure 7. Level of trust in the ecological agroalimentary products in the case of those who do not buy such products.

Actually, trust here conveys the fact that associating the agroalimentary product with the ecological quality transfers this product from the area of food safety and security. The extra food safety and security may arise from the ecological nature of the agroalimentary product. However, as seen in Figure 8, merely 511 respondents identified the agroalimentary product as ecological based on the label. In other words, only $38.07 \%$ of respondents had ecological certification as the main selection criterion. In the case of the other respondents, certification was not the most important criterion for considering an agroalimentary product as ecological or non-ecological.

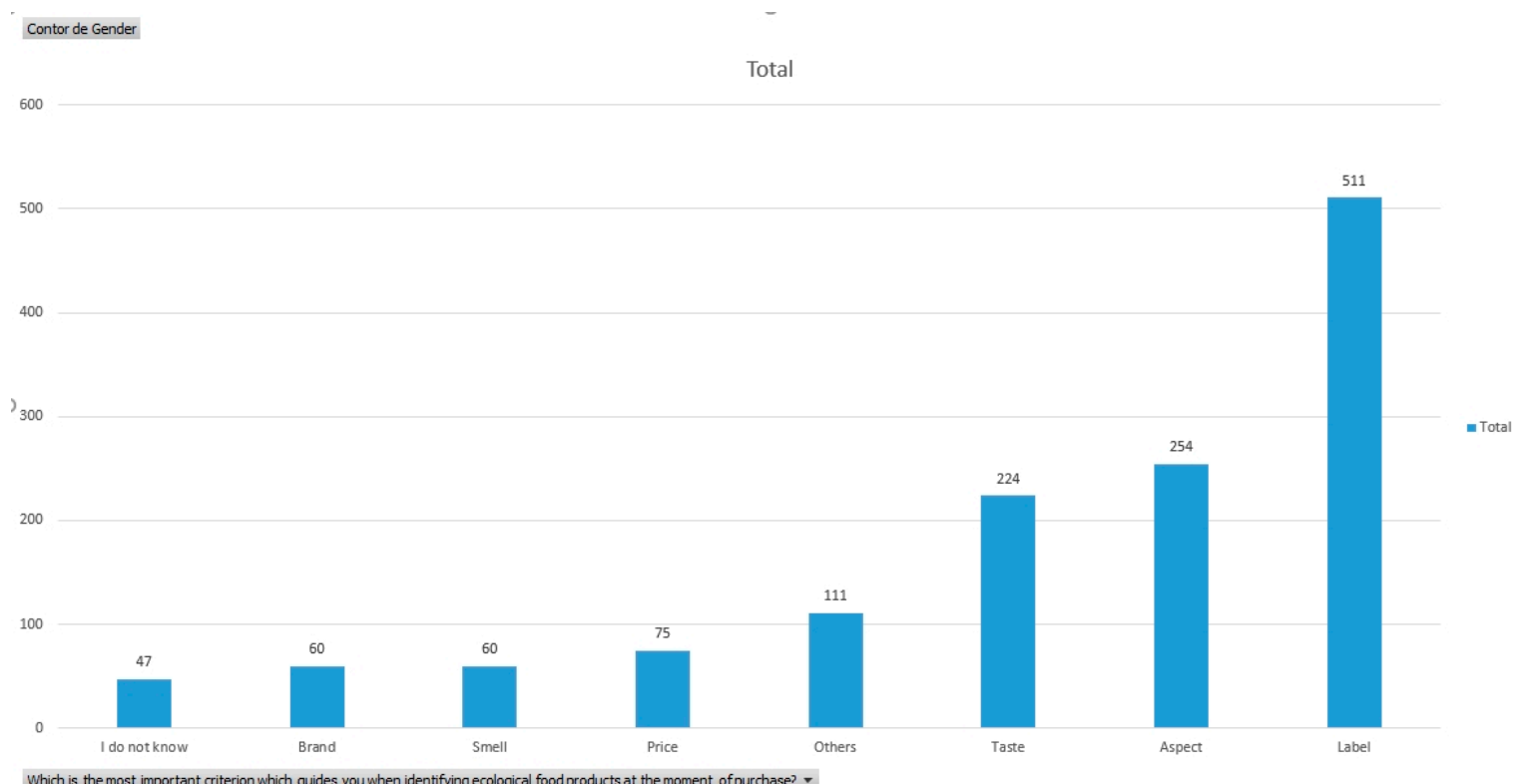

Which is the most important criterion which guides you when identifying ecological food products at the moment of purchase? -

Figure 8. The most important criterion for identifying ecological food products at the moment of purchase.

As noted in Figure 9, out of the 511 respondents who guided themselves based on the label, most subjects bought ecological agroalimentary goods from the supermarket and specialized shops. 
These are, in fact, the very places where these types of products can be found and purchased. These respondents represent the group where the purchase is determined by the official concept of an ecologically certified product. They buy products based on the label as a sign of certification and consider that the definition of ecological agroalimentary product conveys the idea of a certified, organic, or bio product (equivalent terms in Romanian legislation).

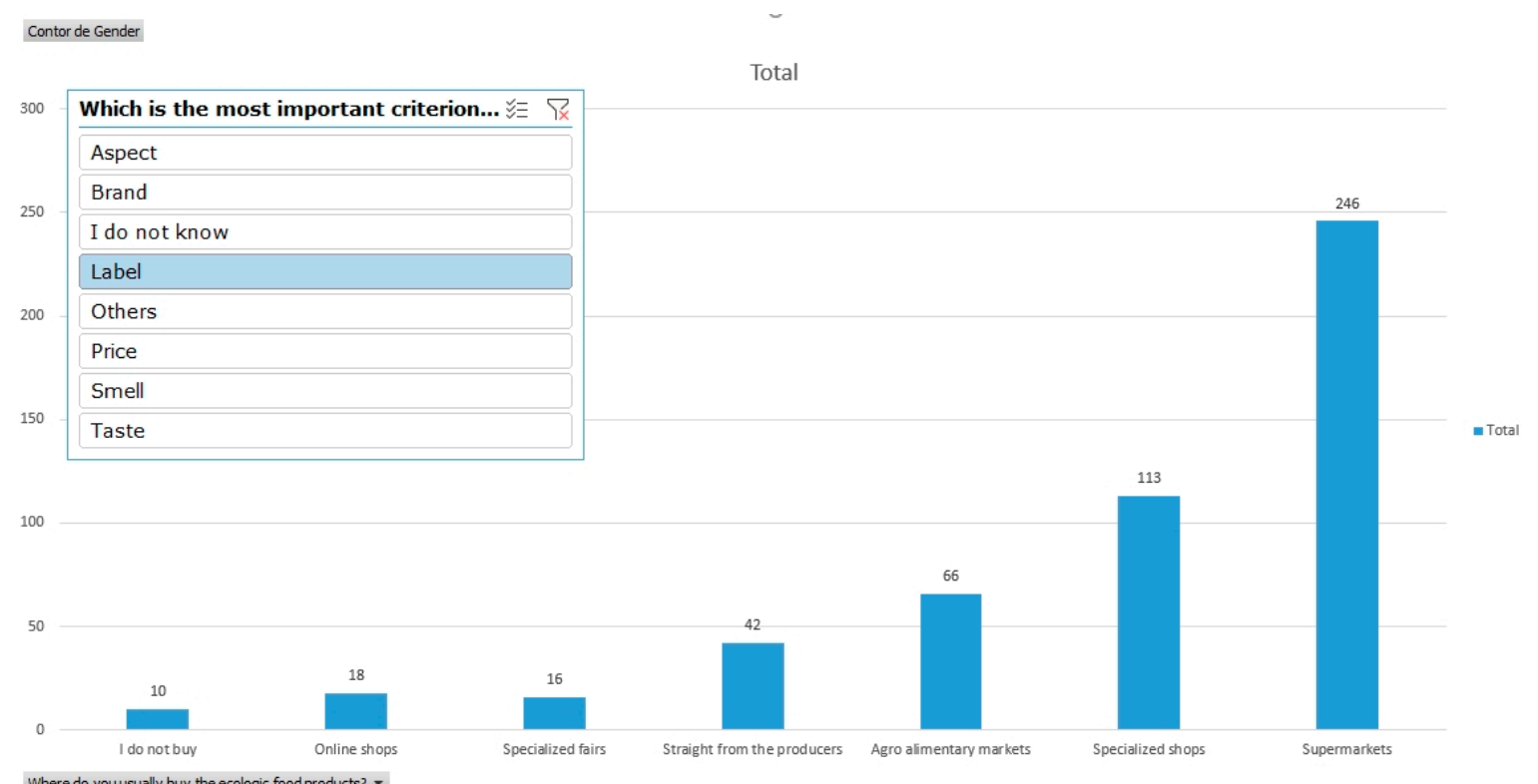

Where do you usually buy the ecologic food products? ?

Figure 9. Where the ecologically agroalimentary products were bought by those who regarded the label as the main identification criterion of these products.

The number of these respondents only reached $331(24.66 \%)$, as seen in Figure 10. The rest had a different approach to the ecological concept with respect to agroalimentary products.

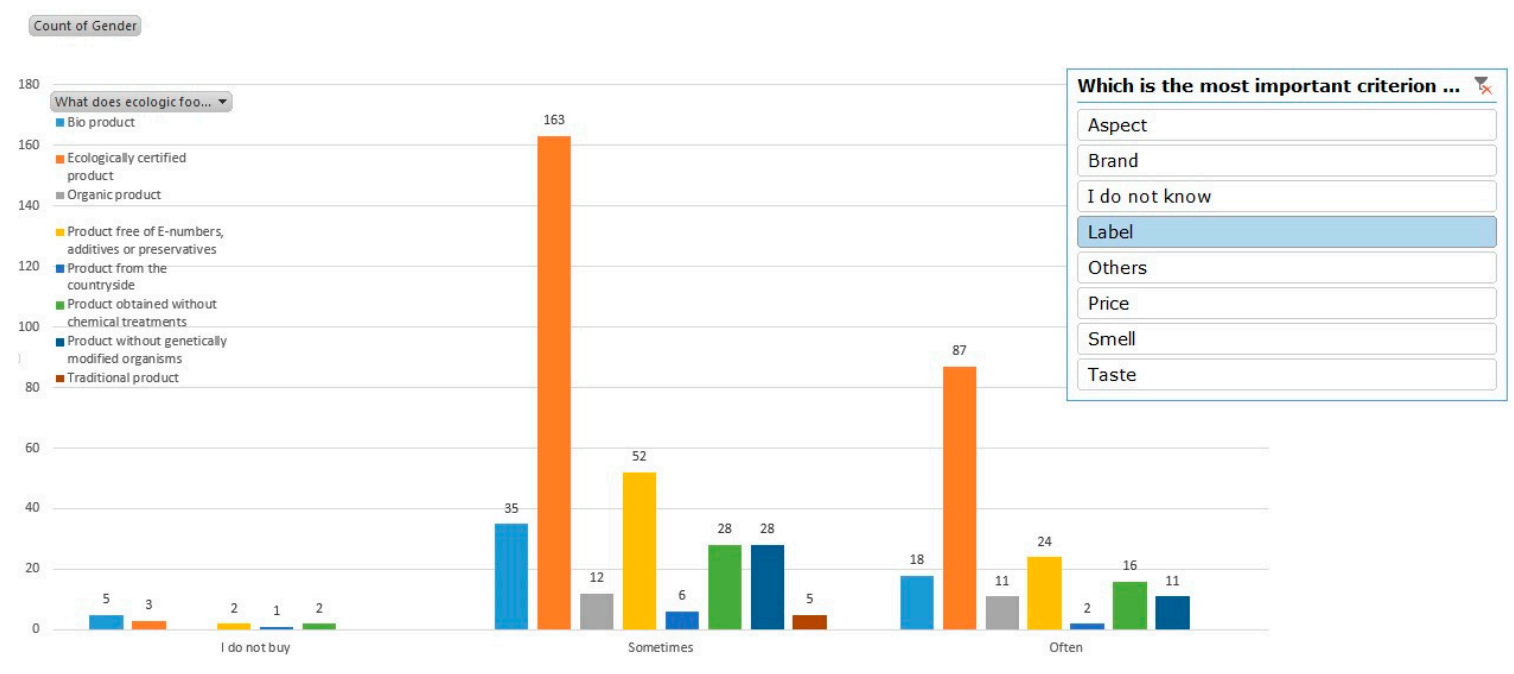

Do you buy ecologic food products? -

Figure 10. Purchase frequency of ecological agroalimentary products depending on the meaning of ecological agroalimentary products for those who identify these products based on label.

Thus, in Figure 11, we note three main groups of consumers:

- Group 1. In quadrant 4, bottom left, we can observe a strong correlation between those who buy ecological agroalimentary products based on label and those who think that the ecological agroalimentary product means an ecologically certified product. 
- Group 2. Especially in the core area of the figure, we can observe relatively strong correlations between those who think that the ecological agroalimentary product represents an organic or bio product, and those whose main purchase reason lies in the lack of additives, chemical treatments, or genetic modifications.

- Group 3. In quadrants 2 and 3 (left side), we can observe that the group of those buying ecological agroalimentary products based on taste, appearance, and smell shares similarities with those who consider the ecological agroalimentary product as a local, traditional, or countryside product.

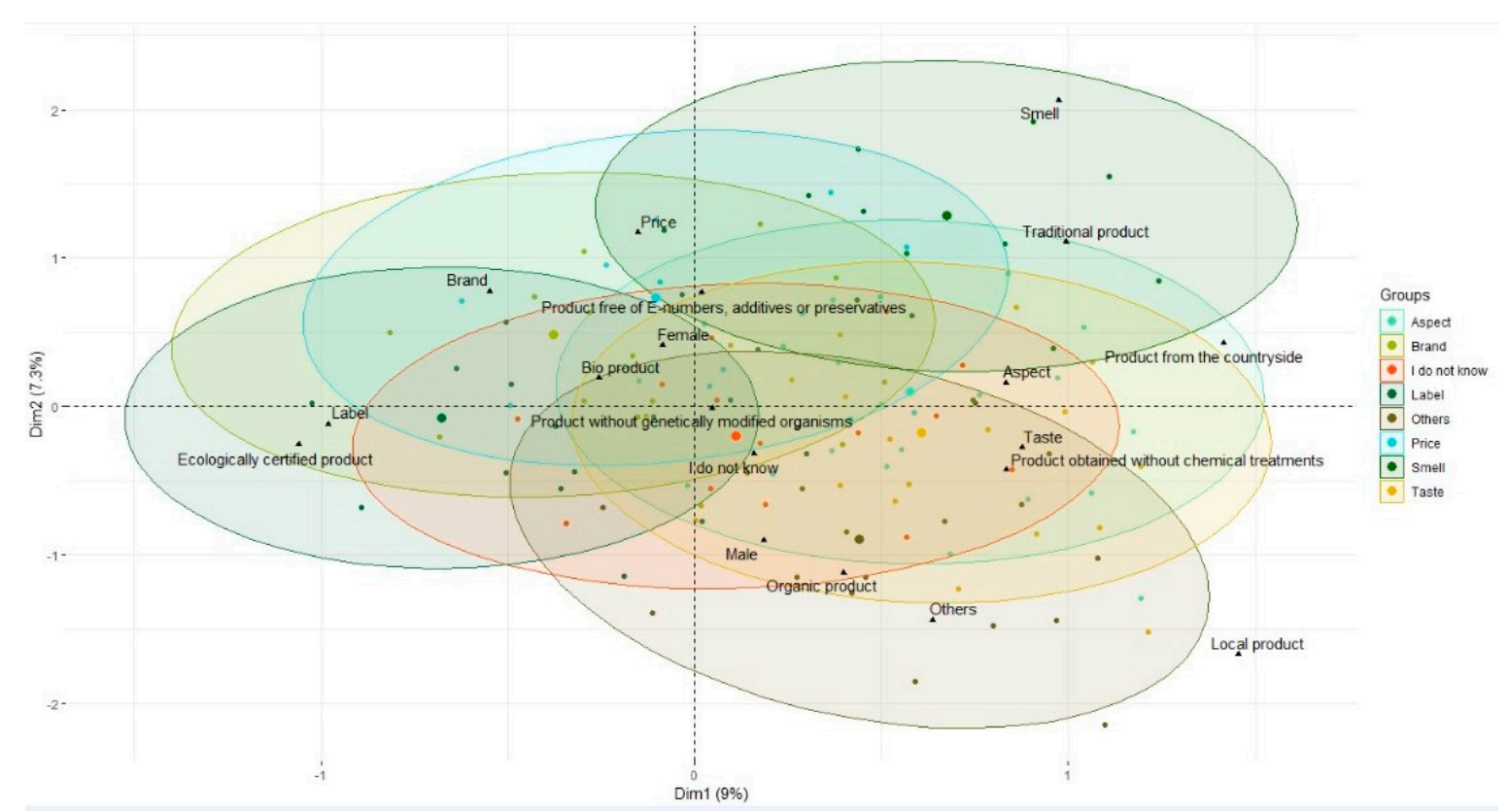

Figure 11. The multi-variable correlation regarding the similarities between what does the ecological agroalimentary product mean and the main identification criterion for this product.

Thus, in the case of groups 2 and 3 (which constitute the tough nucleus of understanding the ecological concept outside the concept of ecologically certified), according to Figure 12, the idea of ecological product changes its meaning in the area of the representations provided by the natural product (394 respondents think that the ecological agroalimentary product is the additive-free and chemical-free product obtained, and also without genetic modifications), local product (129 subjects think that the ecological agroalimentary product is a local or countryside product) and traditional product (38 respondents consider that the ecological agroalimentary product is the traditional product). 


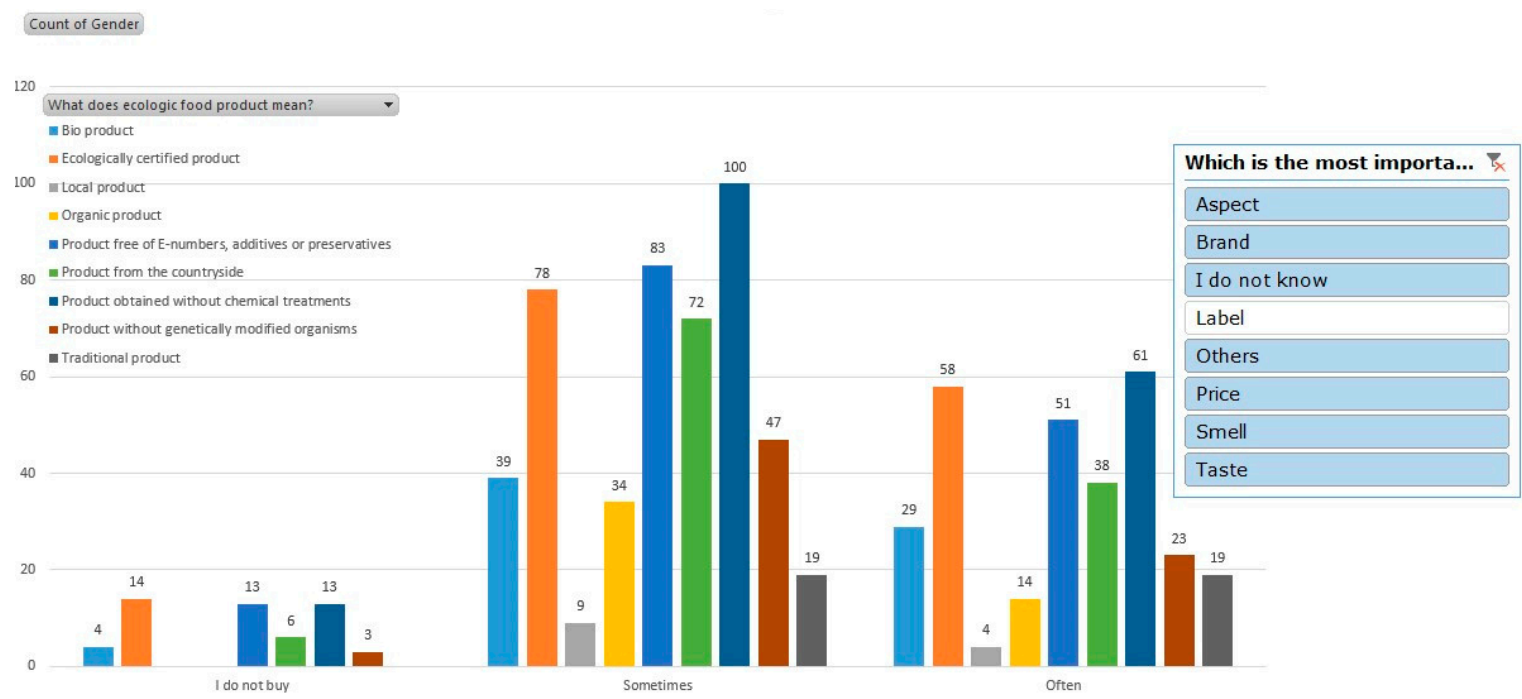

Do you buy ecologic food products? -

Figure 12. The purchase frequency according to the meaning of ecological agroalimentary product in the case of the respondents whose main identification criterion lies in something different from the label of a certified product.

In addition, by leaving aside the filters provided by the main identification criteria of the ecological agroalimentary products, in Figure 13 , we note that 738 respondents $(55.0 \%)$ symbolically configured the idea of ecological agroalimentary products outside the semantics of certified products. This percentage also turned into pressure applied to the epistemology of ecological certification and marketing of the ecological agroalimentary products.

\section{Count of Gender}

What does ecologic food product mean? Total

\section{- Certified Product}

- Not Certified Product

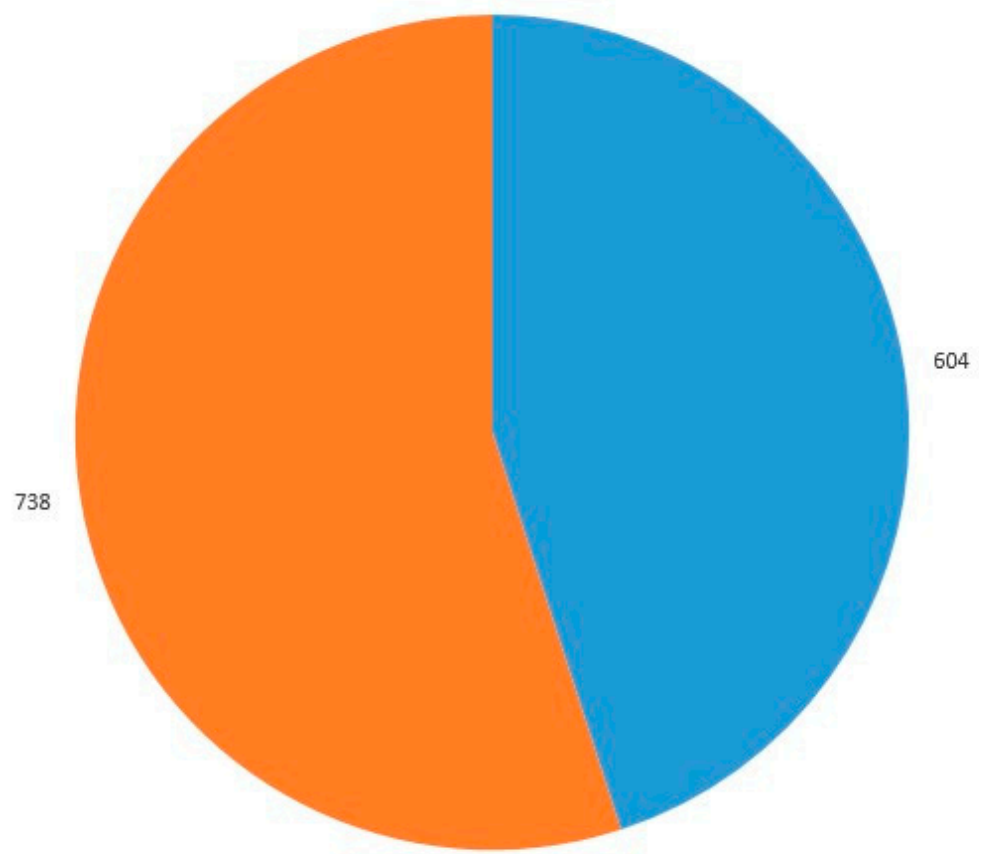

Figure 13. The percentages of understanding the ecological agroalimentary product in the area of certified and uncertified products. 
It is obvious that certain features of ecological agroalimentary products become the very substitutes of this concept and start functioning as its representations. We are dealing with synecdochic thinking here.

This phenomenon is partly determined by the relatively reduced penetration power of the certification concept in the public discourse and collective mentality. As it has been recently officially regulated, the concept of ecologically certified product is not located at the social imaginary level and possesses a relatively low symbolic energy. When competing with other concepts of alimentary consumption (natural, traditional, local, peasant product), it gets to the point where it often overlaps these concepts, or even dissolves itself in their prophylactic references.

Thus, to better understand the key factors of these mental representations and identify solutions addressing a consumer ideology, the interpretations should start reconsidering the aspects previously shown not as deviant phenomena, but as representative data for the symbolic systems of health and consumption. By embracing them as archetypal data at a systemic level, we can observe that the ecological product undergoes the following changes of meaning:

- It comes out of the exclusive conceptual zone of being ecologically certified.

- It is no longer perceived as a necessarily expensive product in comparison with conventional products.

- It no longer has an inaccessible nature for those with small or medium incomes.

- A semantic contamination occurs between the healthy product and ecological product in both directions.

These particular cases of resemanticization are the lines of ethnocentralizing the concept of ecological agroalimentary products. During this process of ethnocentralizing, they are legitimized by a series of narratives that convey the idea of natural, local, or traditional products.

From this point, we can discuss three legitimizing narratives.

\subsubsection{Legitimizing Narratives of Certification Decentralization}

The quality of the agroalimentary products (given by taste, appearance, smell, and perishability) often provides enough arguments for the Romanian urban consumer that they are dealing with a product grown/obtained under natural conditions and is not certified (Figure 14). Under such a legitimizing narrative, paradoxically, the natural character of an agroalimentary product (or supposedly ecological in this direction) becomes a substitute and even more, a competitor at the level of trust invested in the certified agroalimentary product (related to which there are occasional suspicions about respecting the conditions of certification). The sensorial implication in the purchase decision puts the certified product in direct competition with the uncertified product, especially when the latter has a high sensorial impact upon the consumer; "flavorful tomatoes", "vegetables from old times", and "countryside products" are expressions frequently related to the imagination of the urban consumer. Thus, taste, smell, appearance, and the fact that the products are on the stand of a local producer become strong selection criteria by which an uncertified product is perceived as more valuable than a certified product. 


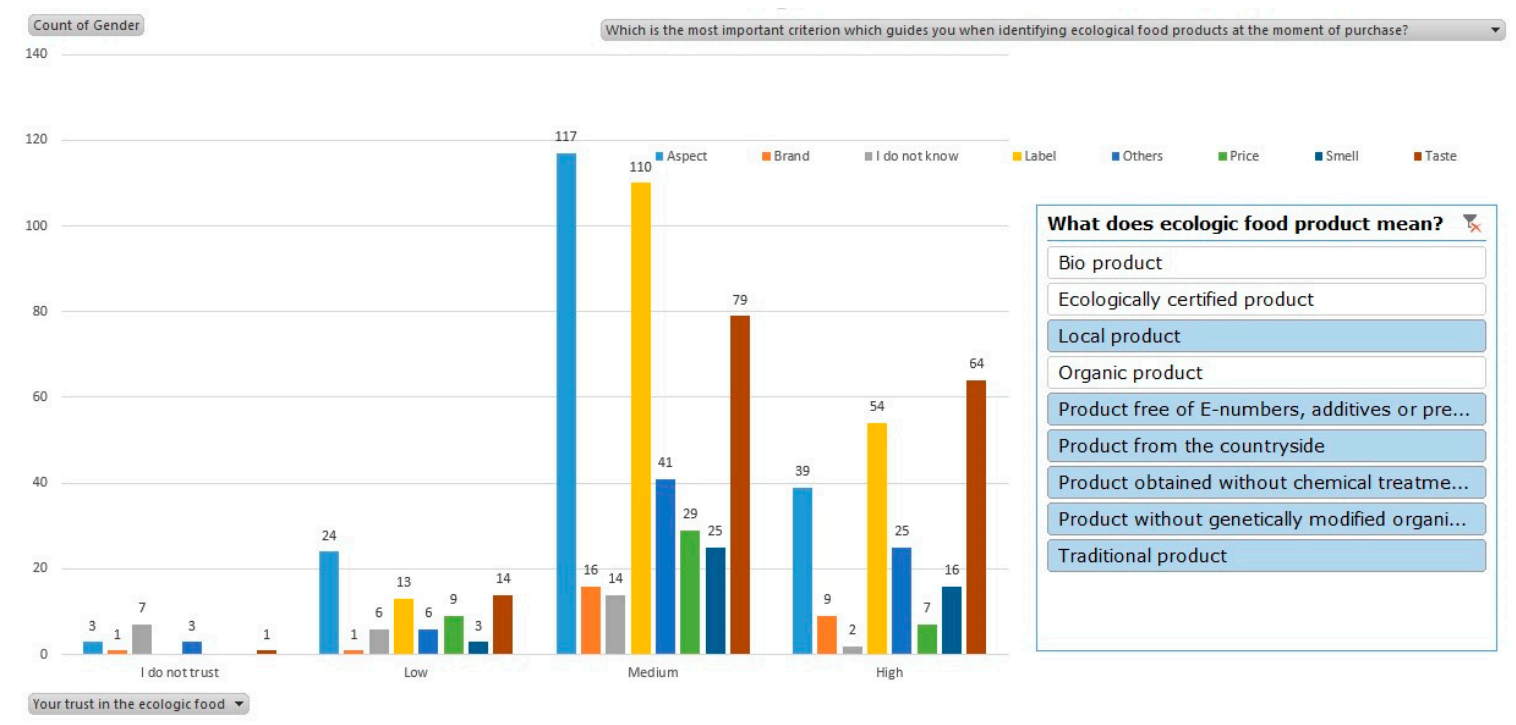

Figure 14. The main selection criterion of the ecological agroalimentary products, according to the level of trust and for the consumers who do not see the meaning of the ecological agroalimentary product as an ecologically certified product, organic, or bio product.

In this context, there is also another legitimizing narrative that relates to the perception between imported and domestic products. The Romanian consumer is more of a person who remembers than inquires. Hence, their memory is a key factor in formulating the purchase options. Moreover, domestic products have a higher success of triggering memories as they employ the most experiences gathered on food consumption over time. In this way, Romanian products gain slightly more value as a healthier product (and are also perceived as more ecological) than the imported products.

Thus, there emerges a localization phenomenon of the agroalimentary product and comes from a very strong identitary lineage as the rural space or countryside is symbolically seen as the place where parents, grandparents, and forefathers live or lived. Thus, rural products have an intensely familiar significance for the Romanian urban consumer.

\subsubsection{Legitimizing the Narratives of Accessibility}

Regarding the legitimization of accessibility, one of the most common narratives refers to the idea of fair price. Thus, in the Romanian public space, there are frequent discourses claiming that peasant work is not duly respected since they struggle and have basic subsistence difficulties. This type of discourse has an interesting consequence on the legitimizing level of the peasant product as an ecological product: the ideological algorithm provides enough arguments for supporting the idea that the limited resources of some peasants force them to produce in a durable and sustainable system (by using classic peasant available resources). Thus, the products obtained are not treated with substances coming from outside the farm, and are seen as natural, and therefore, ecological products. This is the reason why peasant agroalimentary products purchased at accessible prices at the farmers' markets are regarded by the Romanian urban consumer as products obtained in ecological circumstances (provided that there are certain trust networks toward some producers in the farmers' market). Concerning these discourses, it is necessary to mention that Romanian urban consumers are poorly informed about the existing subsidies for the rural environment, even in the case of conventional agriculture.

Another narrative built through the trust gained of farmers' market is related to the reliability perceived by the Romanian urban consumer toward certain producers whose products have earned their trust over time. They are seen as producers of tradition who are reliable and do not use chemical treatments, but are not interested in becoming certified either to keep prices as low as possible, or due to the lack of time and energy. Such preconceptions are not entirely unjustified. Many small rural 
producers would rather base their activity in the family's inherited traditions than move to a certified production system.

3.4.3. Legitimizing Narratives of Overlapping the Concept of an Ecological Product with the Concept of a Healthy Product

When legitimizing narratives of overlapping the concept of an ecological product with the concept of a healthy product, the first thing we need to mention is the semantic contamination between a healthy product and an ecological product. At the mental level of the Romanian urban consumer, a paralogism emerges: if everything ecological is healthy, then everything healthy is ecological. Here, the inversion and contamination zone between the representation of health and that of ecological concept surfaces. It is not the certification that empowers the ecological nature, but the nature of a healthy product.

Therefore, everything related to the ecological concept changes its meaning and becomes support for the legitimizing narratives of the health symbolic system. The products seen as healthy become the only valid representation of the ecological product.

This appears as a legitimizing narrative of the health universe by consuming ecological agroalimentary products. Based on this, at a mental level, consumption and health adjust themselves as symbolic systems through the consumption of ecological products regarded as healthy consumption. Thus, the ecological value becomes a health condition and health turns into one of the ecological consequences.

Another legitimizing narrative of this overlap derives from the mistrust felt by certain consumers toward certified products. Thus, there are discourses in the public space claiming that some producers do not follow the rules of certification, or that some distributors use non-ecological substances to reduce the perishability of the ecological agroalimentary products. A possible solution in these cases can be by shortening the food chains of supply up to the point of direct sales (where the producer can interact face-to-face with the buyer and inform them about the products offered for sale).

We cannot claim that these legitimizing narratives are pertinent. Further scientific investigations should be conducted in this direction. However, these narratives are relevant within the symbolic universe of the healthy alimentation for the Romanian urban consumer.

\section{Conclusions}

Instead of becoming a certification hallmark, ecological agroalimentary products become a philosophy of selection. Thus, the purchase decision comes out of its automatism and embraces a deliberative character. Out in the public space, the brand of ecological agroalimentary products is more and more semantically changed by a consumer who becomes the user and reshapes it by virtue of what we nowadays call the user experience. From the rhetorical mark of certification, the ecological agroalimentary product turns into a common place of personal strategies and individual purchase decisions. Instead of capitalizing itself in the zone of general common sense, the ecological agroalimentary product moves into the zone of daily common-sense (where it is semantically changed on a regular basis and capitalized at the junction of private and public space).

Are we dealing with the general behavior of the consumer as it is stated that "consumption can be a productive force, creating and (re)creating meaning and underpinning political, economic, social and cultural practices and values" [36]? We are facing pro-active consumption, which is more and more replacing passive consumption.

The consumption society, as expression of hyperconsumption, thus defines an interesting phenomenon. The consumption is experienced individually (in a personal or family context), while the consequences are felt generally. To be able to buy a cheaper product nearby, there must be a supermarket in the area where, if I want to find food products at the lowest possible price, it is possible that they are either nutritionally poor or obtained through the conventional agricultural system, chemically treated, or over-processed. As a recurrence, such situations do not impact upon the whole community, as a 
supermarket opened in my neighborhood involves problems of traffic, air quality, aesthetics of the dwelling area, and so on.

Hence, the consumption society resembles a democratic system where private decisions can be taken, while in the general context, the public phenomena are those determining the ways of life. Moreover, democracy is the most appropriate political system for the consumption society as it turns us into ideal consumers and provides the most consumption opportunities. Additionally, it hard to believe that we could easily give up a consumption society, even if we perceive it as a hedonistic society. Our bodies and experiences or emotions have developed a relationship of comfort and self-treatment with the world of products we acquire, use, or consume. The only moral way of overcoming this relationship can be provided by reconfiguring the consumption world. Lately, it seems that we have been witnessing a new revolution within the consumption society. Thus, gradually, the consumer's decision is determined by the desire to turn the consumption society into a healthy universe.

Our study intends to have an inverse approach. The resemanticization of the ecological concept has been regarded not as the consumer's confusion, but as a mental mechanism by which the consumer tries to bring a healthy order in their purchase behavior of agroalimentary products. This consumer is defined by a self-assumed interpretation of the ecological value of the agroalimentary products and is based on both the critical and hermeneutical attitude that they take part in the phenomenon of ethnocentralizing the concept of ecological agroalimentary products. In short, this consumer seizes a public concept regulated by governance and structured by market phenomena and introduces it into their private space of understanding and acceptance. From the rule formulated within the certification area, the ecology of the agroalimentary products becomes the mental and discursive playground where the Romanian contemporary person reconfigures their position in a world where health and consumption can no longer be understood and accepted unless the starting point comes from the very systems in which they trigger.

Actually, in an ideal world, where the producers fully comply with the guidelines of durability, sustainability, food safety and security, ecological certification would be pointless. The ecological certification is the present-day tool by which the socioeconomic aspects of alimentation are directed to certain standards that help us agree with the health of the environment and population. However, as we have noticed earlier, consumers are inclined to semantically change this concept of ecological agroalimentary product in the comfort of their private space in accordance with their resources, objectives, and mentalities.

Having as a starting point the present study, it is our belief that the entrepreneurial environment from Romania should take into consideration, at least, the following features concerning the marketing strategies and product development:

- From a symbolic point of view, the local product has a heavy impact on the consumer's mentality, at least as powerful as that of an ecologically certified product.

- The short food supply chains have more weight for the purchase decision, although the collective mentality does not currently perceive them in the technical acceptance of this concept.

- To increase the level of trust in the ecologically certified product, the entrepreneurial environment should exert pressure on the governing authority with respect to developing public education programs and increasing the rigorousness of controls on the conditions of producing and distributing these products.

- The entrepreneurial environment should also develop abilities to promote and distribute other types of products which, by ethics of production and distribution, can prove as valuable as the ecologically certified products.

Author Contributions: Conceptualization, I.-S.B., S.R., L.T., and M.B.; Data curation, C.D.V., I.-S.B., and M.B.; Formal analysis, A.B., C.D.V., I.-S.B., S.R., and L.T.; Funding acquisition, A.B.; Investigation, A.B., C.D.V., I.-S.B., S.R., L.T., and M.B.; Methodology, A.B., C.D.V., I.-S.B., S.R., L.T., and M.B.; Project administration, A.B. and M.B.; Software, C.D.V.; Supervision, A.B.; Validation, A.B., C.D.V., L.T., and M.B.; Visualization, C.D.V., I.-S.B., and S.R.; Writing—original draft, A.B., C.D.V., I.-S.B., S.R., L.T., and M.B.; Writing—review \& editing, A.B., C.D.V., 
I.-S.B., S.R., L.T., and M.B. All authors made equal contributions to this paper, and they are therefore all considered first authors.

Funding: This work was supported by a grant from the Ministry of Research and Innovation through Program 1-Development of the National R\&D System, Subprogram 1.2-Institutional Performance-Projects for Excellence Financing in RDI, Contract no. 22PFE/2018 and Program NUCLEU 25N-104/2019.

Acknowledgments: We would like to thank our good friend and colleague, George Bodi, for all his assistance with the statistical analysis instrument of R Programming and for all the advice given during the writing of this article. Thanks go to Sonia Bulei for the English translation. We would like to thank our reviewers for the suggestions that led to improving this material.

Conflicts of Interest: The authors declare no conflict of interest.

\section{References}

1. Bourdieu, P. Distinction: A Social Critique of the Judgement of Taste; Harvard University Press: Cambridge, MA, USA, 1987.

2. Baudrillard, J. The Consumer Society: Myths and Structures; SAGE Publications Ltd.: Thousand Oaks, CA, USA, 2017.

3. Veblen, T. Conspicuous Consumption; Penguin Books: London, UK, 2006.

4. Campbell, C. The Romantic Ethic and the Spirit of Modern Consumerism; Palgrave Macmillan: London, UK, 2018.

5. Thompson, P.B.; Kaplan, D.M. Encyclopedia of Food and Agricultural Ethics; Springer: New York, NY, USA, 2014.

6. Lipovetsky, G. Fericirea Paradoxală: Eseu Asupra Societăţii de Hiperconsum; Polirom: Iasi, Romania, 2007.

7. Butu, A.; Vasiliu, C.D.; Rodino, S.; Brumă, I.-S.; Tanasă, L.; Butu, M. The Anthropological Analysis of the Key Determinants on the Purchase Decision Taken by the Romanian Consumers Regarding the Ecological Agroalimentary Products. Sustainability 2019, 11, 4897. [CrossRef]

8. The R Project for Statistical Computing. Available online: https://www.r-project.org/ (accessed on 30 August 2019).

9. R Core Development Team. A Language and Environment for Statistical Computing; R Core Development Team: Vienna, Austria, 2013.

10. RStudio Team (RStudio Inc.). RStudio: Integrated Development Environment for R; RStudio Team: Boston, MA, USA, 2019.

11. Kassambara, A.; Mundt, F. Package 'Factoextra': Visualization of a Correlation MatrixExtract and Visualize the Results of Multivariate Data Analyses. Available online: https://rdrr.io/cran/factoextra/ (accessed on 28 September 2019).

12. Lê, S.; Josse, J.; Husson, F. FactoMineR: An R Package for Multivariate Analysis. J. Stat. Softw. 2008, 25, 1-18. [CrossRef]

13. Wickham, H. Ggplot2: Elegant Graphics for Data Analysis; Springer: New York, NY, USA, 2016.

14. Lyotard, J.-F. Postmodern Condition. The Postmodern Condition: A Report on Knowledge.; University of Minnesota Press: Minneapolis, MN, USA, 1984.

15. Carrete, L.; Castaño, R.; Felix, R.; Centeno, E.; González, E. Green consumer behavior in an emerging economy: confusion, credibility, and compatibility. J. Consum. Mark. 2012, 29, 470-481. [CrossRef]

16. Chryssochoidis, G. Repercussions of consumer confusion for late introduced differentiated products. Eur. J. Mark. 2000, 34, 705-722. [CrossRef]

17. Horne, R.E. Limits to labels: The role of eco-labels in the assessment of product sustainability and routes to sustainable consumption. Int. J. Consum. Stud. 2009, 33, 175-182. [CrossRef]

18. Săgeată, R.; Bucura, C.; Bud, M.; Toderaş, T.; Gherasim, V. Development of the Tertiary Sector and Its Land-Use Impact in the Built-up Area. Case-Study: Commercial Services in Romania. Int. J. Energy Environ. 2011, 5, 47-56.

19. Dragoş, C.; Vereş, V. Romanian Farmers' Market. A Multinomial Logit Model Approach. Zb. Rad. Ekon. Fak. U Rijeci Časopis Za Ekon. Teor. I Praksu 2007, 25, 291-308.

20. Petrovici, D.A.; Ritson, C. Food Consumption Patterns in Romania. Br. Food J. 2000, 102, 290-308. [CrossRef]

21. ROMPAN: Consumul de Paine in Romania a Scazut in Ultimul Deceniu, Dar Inca se Mentine Peste Media Europeana. Available online: https://www.wall-street.ro/articol/Social/236111/rompan-consumul-depaine-a-scazut-la-82-de-kilograme-pe-locuitor-romanii-se-indreapta-catre-produse-de-calitate.html\#gref (accessed on 30 September 2019). 
22. Hicea, N.S. MADR/Direcția pentru A. J. C. Contribuția Tehnologiei La Dezvoltarea Agriculturii Ecologice Din România. Available online: https://www.transilvaniabusiness.ro/2019/03/25/contributia-tehnologiei-ladezvoltarea-agriculturii-ecologice-din-romania/ (accessed on 28 September 2019).

23. Piaţa Pâinii, Între Tradiţie şi Inovaţie-Arta Alba. Available online: https://artaalba.ro/piata-painii-intretraditie-si-inovatie/ (accessed on 28 September 2019).

24. Oua Ecologice. Available online: http://www.ouaecologice.ro/index.php/despre-noi/2-page/2-oua-ecologice (accessed on 28 September 2019).

25. Suciu, A.I.; Culea, M. The Risk of Losing National Identity in the Twenty-First Century Romania, or National Identity from Adaptation to Self-Censorship. Khazar J. Humanit. Soc. Sci. 2015, 18, 13-34.

26. Jean Vasile, A.; Raluca Andreea, I.; Popescu, G.H.; Elvira, N.; Marian, Z. Implications of Agricultural Bioenergy Crop Production and Prices in Changing the Land Use Paradigm-The Case of Romania. Land Use Policy 2016, 50, 399-407. [CrossRef]

27. Cozmei, V. Consumul de Bere în România. Available online: https://economie.hotnews.ro/stiri-companii23077937-consumul-bere-romania-85-litri-cap-locuitor-2018-berea-fara-alcool-creste-30-iar-berea-petscade-pentru-prima-data-sub-50-din-piata-locala.htm (accessed on 29 September 2019).

28. Coordinates of living standard in Romania. Population income and consumption in 2015, 2016, 2017, 2018 - National Institute of Statistics, Romania. 2019. Available online: http://www.insse.ro/cms/en/tags/ coordinates-living-standard-romania-population-income-and-consumption (accessed on 24 October 2019).

29. Padel, S.; Foster, C. Exploring the Gap between Attitudes and Behaviour: Understanding Why Consumers Buy or Do Not Buy Organic Food. Br. Food J. 2005, 107, 606-625. [CrossRef]

30. Vietoris, V.; Kozelová, D.; Mellen, M.; Chreneková, M.; Potclan, J.E.; Fikselová, M.; Kopkáš, P.; Horská, E. Analysis of Consumer Preferences at Organic Food Purchase in Romania. Pol. J. Food Nutr. Sci. 2016, 66, 139-146. [CrossRef]

31. Rusali, M.; Gavrilescu, C. Competitive Advantages and Disadvantages in Romania's Agri-Food Trade-Trends and Challenges. In Proceedings of the International Congress, Ghent, Belgium, 26-29 August 2008.

32. Ungureanu, M.I.; Gheorghe, A.; Voinea, S..A. Patients Are Denied Care Because of Corruption in Romania. Lancet 2017, 230, 2139. [CrossRef]

33. Percepții Asupra Sistemului Medical Românesc și Asupra Asigurărilor Private de Sănătate. Available online: http://www.ires.com.ro/articol/152/percep-ii-asupra-sistemului-medical-romanesc-siasupra-asigurarilor-private-de-sanatate (accessed on 28 September 2019).

34. Mihăilescu, V. Etnogeneză Și Țuică; Polirom: Iasi, Romania, 2018.

35. Seale, C. Health and Media: An Overview. Sociol. Heal. Illn. 2003, 25, 513-531. [CrossRef]

36. Jayne, M. Cities and Consumption (Routledge Critical Introductions to Urbanism and the City); Routledge: London, UK; New York, NY, USA, 2006.

(C) 2019 by the authors. Licensee MDPI, Basel, Switzerland. This article is an open access article distributed under the terms and conditions of the Creative Commons Attribution (CC BY) license (http://creativecommons.org/licenses/by/4.0/). 